\title{
The impact of composts prepared from different organic waste on the total number of soil microorganisms
}

\author{
${ }^{1}$ Wiera Michalcewicz, ${ }^{2}$ Czesław Wołoszyk, ${ }^{2}$ Krzysztof Balcer \\ ${ }^{1}$ Akademia Rolnicza, Katedra Mikrobiologii i Biotechnologii Środowiska, ul. J. Stowackiego 17, 71-434 Szczecin, Poland \\ ${ }^{2}$ Akademia Rolnicza, Katedra Chemii Środowiska, ul. J. Stowackiego 17, 71-434 Szczecin, Poland
}

\begin{abstract}
In a two-factor pot experiment impact of two doses of six types of composts prepared from the municipal sewage sludge with an addition of canteen waste, wheat straw and cocoa husk on the total number of bacteria, actinomycetes and fungi in the soil were exmined. The light soil used in the experiment was taken from the Ap level of an arable field. On all the objects with composts there was mineral NPK fertilization applied, the control object was fertilized with the NPK only. The test plant was grass Festulolium which was harvested three times and after the third cut the samples of the soil were taken for microbiological analyses.

The conducted research shows that the number of microorganisms in soil was dependent on the dose and the type of the compost. The second dose of the compost, in comparison with the control object, in most composts considerably increased the number of bacteria and the first dose increased the number of actinomycetes. However, the number of fungi, in most cases, with both doses of composts, was lower than in the soil from the control object. The highest number of bacteria was noticed on the object with the comost prepared from $35 \%$ sewage sludge $+35 \%$ canteen waste $+30 \%$ straw and actinomycetes on the object with the compost prepared from $35 \%$ sewage sludge $+35 \%$ canteen waste $+30 \%$ cocoa husk. The development of the soil fungi was restrained in the highest degree by the first dose of the compost prepared from $35 \%$ sewage sludge $+35 \%$ canteen waste $+15 \%$ straw $+15 \%$ cocoa husk and by the second dose of the compost prepared from $70 \%$ sewage sludge $+30 \%$ straw.
\end{abstract}

Keywords: composts, soil, bacteria, actinomycetes, fungi.

Presented at VII Conference Wasteless Technologies and Waste Management in Chemical Industry and Agriculture, Międzyzdroje, 12 - 15 June, 2007.

\section{INTRODUCTION}

Every year an increasing number of sewage treatment plants generate bigger and bigger amounts of waste in the form of sewage sludge, which caused various problems with their appropriate and rational management. From among many ways of the utilization and also the neutralization of sewage sludge special attention should be paid to the application of this waste in agriculture, especially after its previous composting process $\mathbf{s}^{\mathbf{1}, 2,3}$. Composting of sewage sludge, often with the participation of other waste (cereal straw, bark, cocoa husk, etc.), causes a decrease of their capacity as well as decontaminates their harmul influence on the environment. The processed sewage sludge, if it does not contain excessive contents of heavy metals and is not sanitary contaminated, can be used as a fertilizer for some of the arable and decorative plants as well as for soil reclamation ${ }^{5}$. The fertilizing value of the municipal sewage sludge is quite wellknown, but in connection with the newer legislative regulations, the problems with the management of the substances, which not long ago were a fodder for animals, has appeared. The change of utilization concerns the canteen waste, which are currently no longer intended to feed animals and are deposited on landfill sites. Still scanty investigations show that canteen waste present quite a considerable fertilizing value. However, for their huge hydration and the content of the undecomposed components they should be composted with an addition of the components which contain suitable microorganisms (e.g. sewage sludge) and with the components which increase the amount of dry matter (e.g. cereal straw, cocoa husk). Few publications concerning the influence of the composted sewage sludge on the soil biological activity and at the same time many research on the possibility of their agricultural utilization, justifies taking up the hereby examination, which aim was to describe the impact of different composts on the total number of the bacteria, actinomycetes and fungi in the soil.

\section{MATERIAL AND METHODS}

Within the confines of the research 6 types of composts with a different participation of the dry matter components were prepared. Table 1 shows the composition of composts.

The sewage sludge came from a sewage treatment plant in Stargard Szczeciński. The process of the decomposition of composts was conducted over 360 days and after that time composts were applied to the soil. Solum in the pot experiment was the light soil from the Ap level of the arable field and it was characterized by the acid reaction, $11,6 \mathrm{~g} \cdot \mathrm{kg}^{-1}$ of the organic carbon, $0,84 \mathrm{~g} \cdot \mathrm{kg}^{-1}$ of the total nitrogen and medium content of available P,K and $\mathrm{Mg}$. In the twofactor scheme of the research the first factor was 6 types of composts, the second factor was two doses of composts, the first corresponds to 0,501 and the second to $1,503 \mathrm{~g}$ N per pot. Mineral NPK fertilization was applied on all the objects with composts $(\mathrm{N}-0,30 \mathrm{~g}, \mathrm{P}-0,0654 \mathrm{~g}$, K- $0,149 \mathrm{~g}$ per pot). The soil with the NPK fertilization only was the control object. The test plant was grass (Festulolium), which was harvested 3 times and after the third cut the soil samples were taken for microbiological analyses. The total number of the bacteria was estimated 
Table 1. Shows the composition of composts

\begin{tabular}{|c|l|}
\hline $\begin{array}{c}\text { Number of } \\
\text { objects }\end{array}$ & \multicolumn{1}{c|}{ Type of compost } \\
\hline 1 & \multicolumn{1}{|c|}{ I dose of composts + NPK } \\
\hline 2 & $\begin{array}{l}\text { Compost }-70 \% \text { sewage sludge }+30 \% \text { straw } \\
\text { waste }+30 \% \text { straw }\end{array}$ \\
\hline 3 & $\begin{array}{l}\text { Compost }-70 \% \text { sewage sludge }+30 \% \text { cocoa } \\
\text { husk }\end{array}$ \\
\hline 4 & $\begin{array}{l}\text { Compost }-35 \% \text { sewage sludge }+35 \% \text { canteen } \\
\text { waste }+30 \% \text { cocoa husk }\end{array}$ \\
\hline 5 & $\begin{array}{l}\text { Compost }-70 \% \text { sewage sludge }+15 \% \text { straw }+ \\
15 \% \text { cocoa husk }\end{array}$ \\
\hline 6 & $\begin{array}{l}\text { Compost }-35 \% \text { sewage sludge }+35 \% \text { canteen } \\
\text { waste }+15 \% \text { straw }+15 \% \text { cocoa husk }\end{array}$ \\
\hline \multicolumn{1}{|l|}{ Il dose of composts + NPK } \\
\hline 7 & Compost $-70 \%$ sewage sludge $+30 \%$ straw \\
\hline 8 & $\begin{array}{l}\text { Compost }-35 \% \text { sewage sludge }+35 \% \text { canteen } \\
\text { waste }+30 \% \text { straw }\end{array}$ \\
\hline 9 & $\begin{array}{l}\text { Compost }-70 \% \text { sewage sludge }+30 \% \text { cocoa } \\
\text { husk }\end{array}$ \\
\hline 10 & $\begin{array}{l}\text { Compost }-35 \% \text { sewage sludge }+35 \% \text { canteen } \\
\text { waste }+30 \% \text { cocoa husk }\end{array}$ \\
\hline 11 & $\begin{array}{l}\text { Compost }-70 \% \text { sewage sludge }+15 \% \text { straw }+ \\
15 \% \text { cocoa husk }\end{array}$ \\
\hline 12 & $\begin{array}{l}\text { Compost }-35 \% \text { sewage sludge }+35 \% \text { canteen } \\
\text { waste }+15 \% \text { straw }+15 \% \text { cocoa husk }\end{array}$ \\
\hline 13 & Control (with mineral NPK fertilization) \\
\hline
\end{tabular}

on Bunt-Rovira `s ${ }^{4}$ substratum, fungi on Martin`s medium with Bengal rose ${ }^{5}$ and actinomycetes on Kuster` ${ }^{6}{ }^{6}$ substratum.

The obtained results were transformed and then statistically verified using a variate analysis.

\section{RESULTS AND DISCUSSION}

Figure 1 shows the percentage participation of the number of bacteria, actinomycetes and fungi in the soil from the objects fertilized with composts and NPK, in comparison with the exclusive NPK fertilization - assumed as $100 \%$.

Changes in the number of microorganisms in the soil were dependent on the type of the compost and on the dose. On the objects with the first dose of composts, in most cases, the number of bacteria was 10 to $38 \%$ lower, in comparison with control. However, the soil from the objects with the second dose of composts was characterized by the increase in the number of bacteria from 14 to $266 \%$ - with the exception of the object fertilized with the compost prepared from $70 \%$ sewage sludge $+30 \%$ straw.

The lowest increase in the number of bacteria was stated in the soil fertilized with the compost prepared from $35 \%$ sewage sludge $+35 \%$ canteen waste $+15 \%$ straw $+15 \%$ cocoa husk and the highest increase in the soil from the object with the composts prepared from $35 \%$ sewage sludge $+35 \%$ canteen waste $+30 \%$ straw. On all the objects with the first dose the significant increase in the number of actinomycetes in the soil was obtained - with the exception of the object on which the compost prepared from $70 \%$ sewage sludge $+30 \%$ straw was applied.

The average increase in the number of actinomycetes in the soil varied from 30 to $118 \%$. As a result of the application of the second dose of composts, only on the object with the compost prepared from $70 \%$ sewage sludge + $30 \%$ straw, the number of actinomycetes increased significantly (by 52\%) and on the rest of the objects it was from 28 to $48 \%$ lower than on the control.
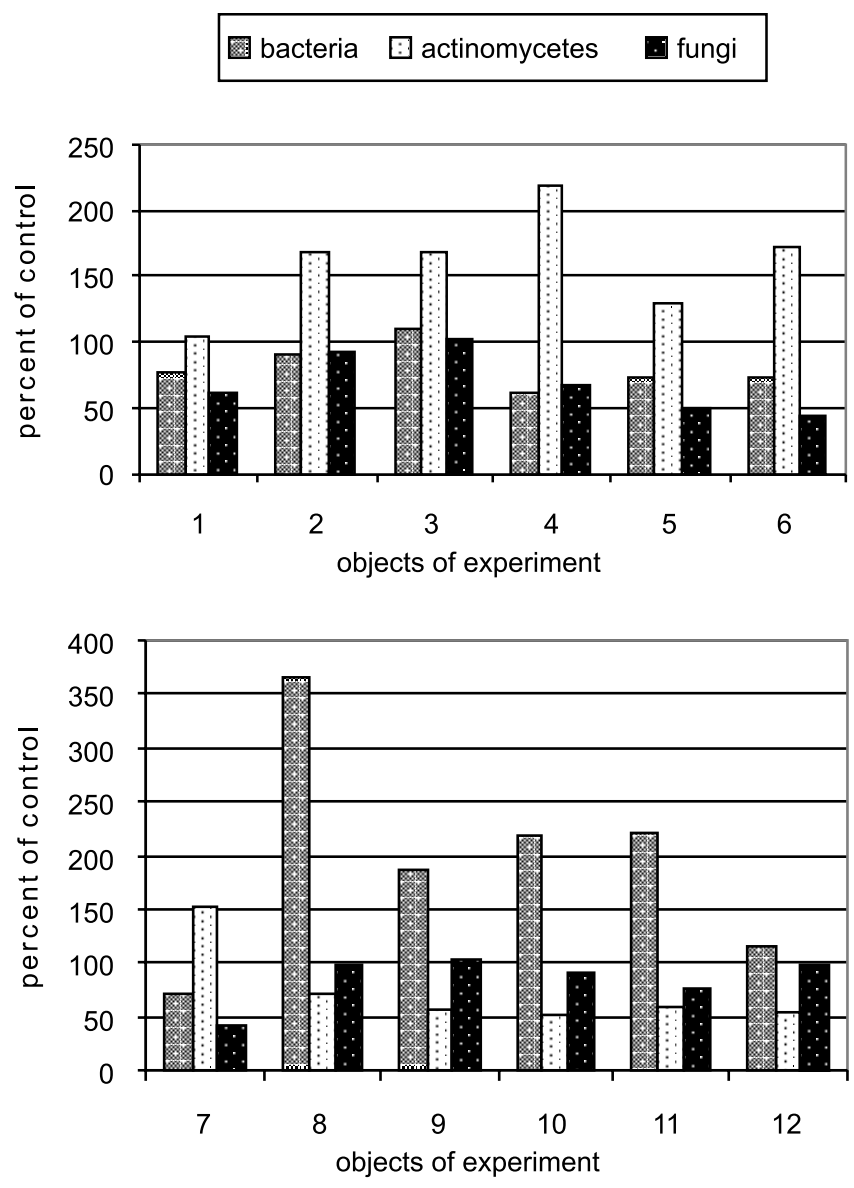

Figure 1. The impact of composts on the number of microorganisms, in comparison with the NPK fertilized soil.

The number of fungi in the soil on objects with I and II dose of compost prepared from $70 \%$ sewage sludge + $30 \%$ cocoa husk, surpassed the number from the control object insignificantly. However, in the soil from the other objects the number of that group of microorganisms was lower, especially in the soil fertilized with I dose of the compost prepared from $35 \%$ sewage sludge $+35 \%$ canteen waste $+15 \%$ straw $+15 \%$ cocoa husk and with II dose of the compost prepared from $70 \%$ sewage sludge + $30 \%$ straw (by about $56 \%$ ).

The degree of the development of the microorganisms could be considered as a measure of the soil biological activity, which is a function of its physical and chemical properties as well as the agricultural factors. Fungi have substantial participation in the settlement of the soil by microorganisms. Among the degree development of bacteria and actinomycetes, in relation to the development of fungi in the soil, specific proportions occur. An intensive development of bacteria and actinomycetes replies to a less intensive development of fungi and vice versa. This relationship is expressed by the degree development of microorganisms ${ }^{7}$ (DDM), which is the ratio of the sum of bacteria and actinomycetes to the number of fungi. The higher value of this index, the relatively weaker development of fungi. From the soil fertility point of view, the increased development of fungi is an unfavourable situation. In the conducted experiment the highest values of that index were noticed in the soil fertilized with the second dose of composts prepared from $35 \%$ sewage sludge $+35 \%$ canteen waste $+30 \%$ straw as well as $70 \%$ sewage sludge $+15 \%$ straw $+15 \%$ cocoa husk (Fig. 2.) 


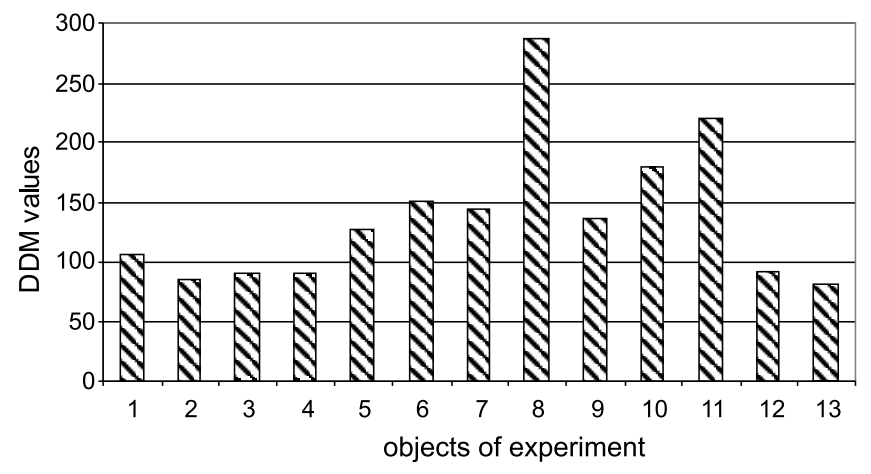

Figure 2. The impact of composts on the value of the DDM index

It could point to an increase of fertility of the soil amended with the composts pre-pared from sewage sludge and other components. When summarizing the obtained results it should be stated that addition of the composted sewage sludge to the soil, caused in most cases a significant increase in the number of bacteria and actinomycetes, as well as a decrease in the number of fungi, in comparison with the not fertilized soil.

The stimulating effect of the raw and com-posted sewage sludge on the number of bacteria and actinomycetes has been confirmed in the research of other authors. They stated the growth of organotrophic, ammonifying and nitrifying bacteria in the soil fertilized with sewage sludge $\mathbf{8 , 9 , 1 0 , 1 1 , 1 2}$. The huge number of these microorganisms in the soil fertilized with the compost prepared from sewage sludge is, first of all, connected with a high content of organic matter and total nitrogen ${ }^{13,14}$.

In the hereby research a decrease in the number of the soil fungi was noticed on most of the objects of experiment, in comparison with the control soil, which finds confirmation in the research of Thi Bich Loc and Piontek ${ }^{14}$.

The composted sewage sludge used as an organic fertilizer presents a valuable source of nutrients for plants as well as it can increase the biological activity of the soil ${ }^{15,16}$.

\section{CONCLUSIONS}

1. The number of bacteria, actinomycetes and fungi in the soil was significantly differentiated by the fertilizing of the composts prepared from sewage sludge with the addition of canteen waste, wheat straw and cocoa husk.

2. The second dose of the compost, in comparison with the control object, in most composts considerably increased the number of bacteria and the first dose increased the number of actinomycetes.

3. The highest number of bacteria was noticed on the object with compost prepared from $35 \%$ sewage sludge + $35 \%$ canteen waste $+30 \%$ straw and actinomycetes on the object with compost prepared from $35 \%$ sewage sludge $+35 \%$ canteen waste $+30 \%$ cocoa husk

4. The development of soil fungi was restrained to the highest degree by the first dose of the compost prepared from $35 \%$ sewage sludge $+35 \%$ canteen waste $+15 \%$ straw $+15 \%$ cocoa husk and by the second dose of the compost prepared from $70 \%$ sewage sludge $+30 \%$ straw. tional Programme (IROP), financed by European Social Fund and national budget.

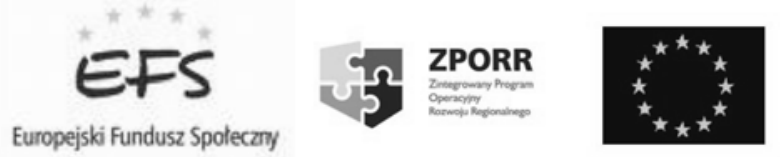

\section{LITERATURE CITED}

(1) Bernacka J., Pawłowska L.: Zagospodarowanie i wykorzystanie osadów z miejskich oczyszczalni ścieków. IOŚ, 1994, 9 - 42.

(2) Kalembasa S., Kalembasa D.: Wybrane chemiczne i biologiczne metody przeróbki osadów ściekowych. Biotechnologia, 1997, 1, 36, 45 - 51.

(3) Łomotowski J., Szpindor A.: Nowoczesne systemy oczyszczania ścieków. Wydawnictwo „Arkady”, Warszawa, 1999, 377 - 395

(4) Bunt Y. S., Rovira A.D.: Microbiological studies of some subarctic soil. J. Soil Sci., 1955, 6: 119 - 128.

(5) Martin J. P.: Use of acid, Bengal rose and streptomycin in the plate method for estimating soil fungi. J. Soil Sci. 1950, 6, 215.

(6) Kuster E., Willami S.T.: Selection of media for isolation of Streptomycetes. Nature, London, 1964, 202, 928 - 929.

(7) Myśków W.: Próby wykorzystania wskaźników aktywności mikrobiologicznej do oceny żyzności gleby. Postępy Mikrobiologii, 1981, z. 3/4, 173 - 192.

(8) Michalcewicz W., Maślach B.: Wpływ kompostowanych osadów pościekowych z oczyszczalni w Goleniowie na aktywność biologiczną gleb. I. Porównanie liczebności bakterii, grzybów, promieniowców oraz bakterii grupy coli w glebie nawożonej kompostowanymi osadami ściekowymi. [w] „Drobnoustroje w środowisku. Występowanie, aktywność i znaczenie", AR Kraków 1997, 467 - 475.

(9) Thi Bich Loc.: Liczebność niektórych grup drobnoustrojów w surowym osadzie i po jego kompostowaniu, Folia Univ. Agric. Stetin, Agricult. 2000 a, 211 (84), 355 - 340.

(10) Thi Bich Loc, Piontek M.: Stan ilościowy niektórych bakterii i grzybów w osadzie ścieków komunalnych, Folia Univ. Agric. Stetin, Agricult. 2000 b, 211 (84), 341 - 346.

(11) Wielgosz E.: Liczebność i niektóre parametry aktywności drobnoustrojów w osadzie ścieków komunalnych pod uprawa różnych roślin, Zesz. Probl. Post. Nauk. Rol., 1996, 437, 337 - 340.

(12) Wyszkowska J., Kucharski J., Jarzębska E.: Liczebność drobnoustrojów w glebie zanieczyszczonej osadami ściekowymi, Acta Agraria et Silvestra, 2004, 62, 475 - 483.

(13) Krzywy E., Wołoszyk C., Iżewska A., Krzywy-Gawrońska E.: Wpływ kompostów $\mathrm{z}$ komunalnego osadu ściekowego $\mathrm{z}$ różnymi komponentami na wysokość i skład chemiczny nasion i słomy rzepaku jarego, 2002, Zesz. Probl. Post. Nauk. Rol., 2002, 484, 303 - 317.

(14) Wołoszyk Cz.: Agrochemiczna ocena nawożenia kompostami z komunalnych osadów ściekowych i odpadami prze-mysłowymi. Rozpr. AR Szczec. 2003, 217, 120.

(15) Balton H., Elliot L.F., Popendick R.I., Bezdieck D.F.: Soil microbial biomass and selected soil enzyme activities: effect of fertilization and cropping practices. Soil Biol. Biochem., 1985, 17, 297 - 302.

(16) Kobus J., Czaban J., Gajda A.: Wpływ osadu ściekowego na aktywność biologiczną gleb zdegradowanych i przemiany w nich wegla, azotu, fosforu i cynku. Pam. Puławski, 1990, z. 96, 121 - 13.

The co-author (Krzysztof Balcer) is a stipendiary in confines of 2.6 Acting of the Integrated Regional Opera- 